\title{
A Panel Data: Capital Structure of the Companies Registered in the Jakarta Islamic Index (JII)
}

\author{
Wuryaningsih Dwi Lestari ${ }^{1}$, Anestia Retno Kusumastuti ${ }^{2}$, Ma'ruf ${ }^{3}$, Wafiatun \\ Mukharomah4, Muhammad Sholahuddin ${ }^{5^{*}}$ \\ Muhammad.sholahddin@ums.ac.id ${ }^{5 *}$
}

Program Studi Manajemen, Fakultas Ekonomi dan Bisnis, Universitas Muhammadiyah Surakarta, Jl. A. Yani Tromol Pos 1, Pabelan, Kartasura, Sukoharjo, Jawa Tengah ${ }^{1}$

\begin{abstract}
Abstrak. The aim of this study is to determine several variables that the impact of capital structure of firms listed on the Jakarta Islamic Index. This study uses 40 samples of companies registered in JII 2008-2017 that were analyzed using panel data. The results of this study differ from previous studies, especially on company size and profitability variables not significantly influence capital structure. While the liquidity variable, the company growth opportunity has a negative effect on capital structure. The results of this study contribute to capital market players to be more careful in creating the composition of capital structure, especially in terms of liquidity and growth opportunity of the company. The right capital structure strategy will produce an optimal capital structure by considering the variable liquidity and growth opportunity.
\end{abstract}

Keyword: Capital structure, Jakarta Syariah Index, Panel Data, Company Size, Liquidity.

\section{Pendahuluan}

Memiliki dan menjaga keunggulan kompetitif sangatlah penting untuk keberhasilan dan kelangsungan hidup jangka pendek sekaligus jangka panjang suatu bisnis. Diantara caranya dengan meningkatkan atau memaksimalkan nilai perusahaan tersebut [1]. Untuk mencapai nilai perusahaan yang maksimal, suatu perusahaan tidak terlepas dari masalah pendanaan yang digunakan untuk menunjang kelancaran aktivitasnya. Struktur modal perusahaan mencerminakn kondisi keuangan perusahaan sehingga masalah pendanaan modal merupakan suatu hal yang penting. Dengan demikian, diperlukanya sikap kehati-hatian bagi perusahaan dalam menentukan sumber dana pilihan [2].

Strategi pemenuhan sumber pendananaan sangat berkaitan dengan struktur modal. Struktur modal perusahaan adalah kombinasi tertentu dari hutang pendek, hutang panjang dan ekuitas. Perusahaan dapat memilih di antara banyak alternatif struktur modal.Campuran ideal dari hutang dan ekuitas untuk perusahaan, yaitu yang memaksimalkan nilai perusahaan dan meminimalkan keseluruhan biaya modal [3]. Jadi, struktur modal yaitu bagian terpenting dari strategi pemenuhan pendanaan yang dapat meningkatkan nilai perusahaan dengan menggunakan kombinasi dari hutang dan ekuitas.

Struktur modal yang baik sangat dibutuhkan dalam menunjang keberlangsungan suatu perusahaan. Setiap perusahaan dituntut untuk bisa menghasilkan struktur modal yang optimal meskipun sulit dalam praktiknya. Nilai suatu perusahaan maksimal jika struktur modalnya juga optimal yang terdiri dari campuran antara utang dan ekuitas[4]. Hal ini juga diungkapkan oleh 
Nur \& Siahaan (2016) bahwa pendanaan yang baik merupakan pendanaan yang tidak hanya menggunakan dana dari luar tetapi juga dana yang berasal dari dalam perusahaan.

Untuk dapat menentukan struktur modal yang optimal, perusahaan harus mempertimbangkan variabel-variabel yang mempengaruhinya. Salah satu alasannya karena variabel-variabel tersebut merupakan dasar pertimbangan untuk menentukan struktur modal [5]. Struktur modal banyak di pengaruhi oleh variabel, tetapi dalam penelitian ini variabel yang akan diteliti diantaranya, firm size, liquidity, pofitability, tangibility, dan growth opportunity.

Terdapat berbagai perbedaan hasil penelitian terdahulu mengenai struktur modal. Hal ini disebabkan oleh adanya perbedaan waktu penelitian, jumlah sampel, dan populasi yang diteliti [6].Penelitian yang dilakukan Sheikh \& Qureshi (2017) menunjukkan bahwa struktur modal di pengaruhi oleh ukuran perusahaan dimana ukuran perusahaan berpengaruh positif, tetapi penelitian dari purwahandoko (2017)bahwa struktur modal tidak di pengaruhi oleh ukuran perusahaan dan pertumbuhan perusahaan .Variabel likuiditas dalam penelitian purwahandoko (2017) berpengaruh negatif. Penelitian Hussain dan Miras (2014) menyatakan bahwa terdapat pengaruh signifikan negatif profitabilitas terkait struktur modal kemudian dari penelitian Mustika(2017) menunjukkan bahwa struktur modal tidak di pengaruhi oleh profitabilitas. Variabel tangibility pada penelitian dari Odongo dan Makoaleli(2015) tidak berpengaruh terhadap struktur modal sedangkan penelitian dari Basil \& Taylor(2008) menunjukkan bahwa ada pengaruh positiv tangibility terhadap struktur modal. Kemudian, variabel growth opportunity dalam penelitian Setyawan \& Nuzula (2016) menyatakan bahwa growth opportunity berpengaruh negatif tetapi pada penelitian Wijaya \& Jessica (2018) menunjukkan bahwa struktur modal dipengaruhi oleh growth opportunity.

Dengan adanya perbedaan-perbedaan tersebut, peneliti tertarik untuk melakukan pengujian kembali terkait variabel-variabel yang mempengaruhi struktur modal.

\section{Metode}

Data pada penelitian ini berupa angka-angka sehingga jenis penelitian yang digunakan, yaitu penelitian kuantitatif. Data yang digunakan berasal dari laporan keuangan perusahaan sehingga penelitian ini menggunakan data sekunder[7]. Dalam penelitian ini menggunakan pendekatan asosiatif kausal. Pendekatan ini dipilih karena dilakukan pengukuran hubungan antara variabel independen dan variabel dependen [8].

Laporan keuangan perusahaan yang di gunakan yaitu laporan keuangan yang terdaftar di Jakarta Islamic Index selama periode 2008-2017 yang diperoleh dari www.idx.co.id. Pengumpulan data dilakukan dengan metode studi pustaka. Pengumpulkan, pencatatan, dan pengkajian laporan keuangan perusahaan yang terdaftar di JII selama periode 2008-2017 dilakukan dalam penelitian ini.[9]

Studi ini menggunakan variabel dependen yaitu struktur modal. Sedangkan firm size, liquidity, profitability, tangibility, dan growth opportunity sebagai variabel independen.

a. Struktur Modal

Struktur modal perusahaan adalah kombinasi tertentu dari hutang pendek, hutang panjang dan ekuitas. Sumber dana terdiri dari laba ditahan (retained earning) dan penyertaan kepemilikan perusahaan (ekuitas), sedangkan sumber dana asing berupa hutang [10]. Debt to Equity Ratio (DER) digunakan untuk pengukuran struktur modal [11].

b. Firm Size (Ukuran Perusahaan) 
Ukuran perusahaan dapat diukur atau dilihat dari total aktiva perusahaan pada akhir tahun.Jadi, untuk memenuhi besarnya aktiva suatu perusahaan harus mempertimbangkan faktor ukuran perusahaan dalam menentukan seberapa besar keputusan pendanaan [12]. Total aktiva merupakan bagian penting dalam mengukur besarnya suatu perusahaan, disebabkan total aktiva lebih stabil menjadi tolak ukur dari penjualan yang masih dipengaruhi oleh permintaan dan penawaran .[13]

c. Likuiditas

Likuid tidaknya suatu perusahaan dapat diukur dengan rasio likuiditas. Rasio likuiditas untuk mengukur kemampuan perusahaan untuk membayar semua kewajibannya, baik kewajiban jangka pendek dan jangka panjang, terutama ketika itu dibubarkan (dilikuidasi) [14] Peningkatan current ratio berbanding lurus dengan kemampuan perusahaan membayar hutang jangka pendeknya [15].

d. Profitabilitas

Menurut Guna \& Sampurno (2018), tujuan utama perusahaan didirikan adalah untuk dapat menghasilkan laba. Laba yang dihasilkan pada suatu perusahaan menunjukkan efektivitas dan efisiensi manajemen. Karena itu, perusahaan harus mengetahui kemampuan dalam menghasilkan keuntungan dengan menggunakan rasio profitabilitas. Sehingga rasio profitabilitas merupakan rasio untuk mengukur kemampuan perusahaan dalam memperoleh laba.

\section{e. Tangibility}

Menurut Corina, Murhadi, Wijaya (2017), tangibility yaitu aset tetap perusahaan yang bisa digunakan sebagai jaminan. Dalam menentukan keputusan pendanaan, salah satu variabel penting yang harus diperhatikan, yaitu tangibility. Tangibility adalah gambaran kemampuan aset tetap dalam menjamin hutang yang akan dipinjam oleh suatu perusahaan [16]. Jadi, suatu perusahaan harus memiliki jaminan (collateral) atas hutang yang diperoleh berupa aset tetap yang memadai jika ingin memperoleh pinjaman dari pihak lain.

f. Growth Opportunity

Growth opportunity adalah suatu peluang atau kesempatan perusahaan dalam mencapai tingkat pertumbuhan atau perkembangannya. Jadi, growth opportunity dipakai untuk mengukur seberapa besar peluang atau kesempatan perusahaan untuk terus bertumbuh dan berkembang setiap tahunnya [17]. Perusahaan dengan peluang pertumbuhan tinggi akan berdampak pada peningkatan asimetri informasi, sehingga dalam pendanaannya, perusahaan lebih memilih menggunakan dana internal di tempat pertama (Vo, 2017).

Teknik analisis data yang digunakan dalam penelitian ini ialah data panel, karena perusahaan yang akan diteliti lebih dari satu dan periode yang digunakan juga lebih dari satu. Data panel yaitu data kombinasi time series dan cross section[18]. Sehingga, analisis regresi data panel digunakan dalam studi ini. Pengolahan data yang digunakan dalam penelitian ini menggunakan software Eviews 9. Persamaan analisis model data panel penelitian ini adalah:

$\mathrm{Y}=\beta 0+\beta 1 \mathrm{X} 1$ it $+\beta 2 \mathrm{X} 2$ it $+\beta 3 \mathrm{X} 3$ it $+\beta 4 \mathrm{X} 4$ it $+\beta 5 \mathrm{X} 5$ it $+\mu$

$$
\mathrm{DER}=\beta 0+\beta 1 \text { Size it }+\beta 2 \mathrm{LD} \text { it }+\beta 3 \mathrm{PRO} \text { it }+\beta 4 \mathrm{TANG} \text { it }+\beta 5 \mathrm{GO} \text { it }+\mu
$$

Keterangan:

Y : Struktur Modal (DER)

$\beta 0$ : Konstanta

$\beta 1$ sampai $\beta 5$ : Koefisien regresi dari setiap variabel independen

X1 : Firm Size(Size)

$\mathrm{X} 2$ : Liquidity (LD) 


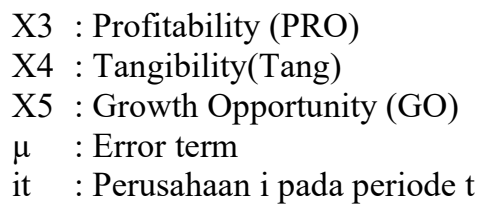

\section{Hasil dan Pembahasan}

Studi ini menggunakan 40 observasi data sekunder sebagai sampel. Nilai probabilitas lebih kecil dari 0,05 menunjukkan bahwa metode yang digunakan adalah fixed effect. Namun apabila value probabilitas lebih dari 0,05 menandakan jika metode yang digunakan lebih tepat menggunakan common effect. Berdasarkan nilai perhitungan diatas, diketahui bahwa nilai probabilitas dari Cross-section Chi-square sebesar 0,000 yang menandakan bahwa nilai chisquare lebih kecil dari 0,05. Jadi, model estimasi yang terbaik, yaitu model fixed effect dan akan dilanjutkan pada uji Hausman.

Asumsinya, apabila nilai probabilitas lebih kecil dari 0,05 maka metode yang lebih tepat menggunakan fixed effect. Namun, apabila tingkat probabilitas lebih dari 0,05 menandakan jika model terpilih adalah random effect. Berdasarkan infoemasi pada tabel nilai probabilitas sebesar $1,000>0,05$, artinya random effect merupakan model yang terpilih adalah.

Persamaan regresi data panel yang diperoleh, yaitu:

DER $=3,009-0,001$ Sizeit $-0,510 \mathrm{LD}$ it $+0,785$ PROit $-1,775$ Tangit $-2,740 \mathrm{GO}$ it $+\mu$

\section{Uji Hipotesis}

1. Hipotesis pertama dalam penelitian ini, yaitu variabel Size memberikan pengaruh positif signifikan terhadap Struktur Modal. Berdasarkan hasil pengujian terlihat bahwa probabilitas dari variabel Size sebesar 0,976>0,05 dengan nilai uji T sebesar -0,031. Hal ini menunjukkan bahwa ditolaknya H1, dan variabel Size tidak memberikan pengaruh nyata terhadap struktur modal. Hasil dari pengujian ini menandakan bahwa struktur modal tidak di pengaruhi oleh ukuran besar kecilnya suatu perusahaan. Jika ukuran suatu perusahaan semakin besar, maka dana internalnya berlimpah sehingga perusahaan tersebut mampu memenuhi kebutuhan pendanaannya dan kecil kemungkinan untuk menggunakan dana dari utang. Penelitian ini sesuai dengan penelitian sebelumya, yaitu dari [19] yang hasilnya juga menunjukkan bahwa tidak ada pengaruh signifikan size terhadap struktur modal.

Disisi lain, hasil tersebut tidak sejalan dengan hipotesis yang dibentuk dalam penelitian dan berbeda pula dengan penelitian yang dilakukan Chandra(2018). Hal ini menandakan jika ukuran perusahaan semakin besar maka semakin besar juga tingkat hutangnya. Dana yang besar cenderung dibutuhkan oleh perusahaan besar untuk memenuhi kebutuhan pendanaannya selain itu perusahaan yang besar juga cenderung mendapatkan kepercayaan yang tinggi dari para investor sehingga perusahaan menjadi lebih mudah untuk melakukan pinjaman.Perbedaaan hasil penelitian diatas dapat disebabkan oleh perbedaan periode dan objek yang digunakan dalam penelitian. 
2. Hipotesis kedua dalam penelitian ini, yaitu variabel likuiditas memiliki pengaruh negatif dan signifikan terhadap Struktur Modal. Berdasarkan hasil pengujian terlihat bahwa nilai probabilitas dari variabel Likuiditas sebesar $0,000<0,05$ yang nilai uji T sebesar $-4,523$. Hal ini menunjukkan bahwa $\mathrm{H} 2$ diterima, terdapat pengaruh negatif dan signifikan dari variabel likuiditas terhadap Struktur Modal.

Hasil penelitian ini sesuai dengan penelitian Wijaya \& Jessica (2018) dan Guna \& Sampurno (2018) .Semakin tinggi tingkat likuiditas suatu perusahaan maka tingkat hutangnya rendah. Hasil studi ini selaras dengan pecking order theory, menyebutkan suatu firma yang tinggi tingkat likuiditasnya mempuyai dana internal cukup besar untuk mendanai kegiatan operasionalnya sehingga proporsi penggunaan hutang relatif rendah.

Akan tetapi penelitian ini memiliki perbedaan dengan hasil penelitian Murti (2014). Hasil penelitian menjelaskan bahwa tidak ada pengaruh likuiditas terhadap struktur modal. Kondisi ini menunjukkan jika dana eksternal atau utang cenderung tidak digunakan oleh perusahaan yang tinggi tingkat likuiditasnya karena dana internal firma tersebut mencukupi guna memenuhi kebutuhan pendanaannya. Perbedaan pada penelitian diatas terjadi karena objek dan periode yang digunakan berbeda.

3. Hipotesis ketiga dalam penelitian ini, yaitu terdapat pengaruh negatif signifikan antara variabel profitabilitas terhadap struktur Modal. Berdasarkan hasil pengujian terlihat bahwa nilai probabilitas dari variabel Profitabilitas sebesar 0,293<0,05 dengan nilai uji T sebesar 1,069. Hal ini mengindikasikan jika H3 ditolak, Struktur Modal tidak dipengaruhi signifikan oleh variabel profitabilitas.

Penelitian yang dilakukan Lestari \& Yarni (2017) sesuai dengan hasil penelitian ini . Teori pecking order juga bersesuaian dengan penelitian ini yaitu semakin tinggi tingkat profitabilitas yang dimiliki perusahaan, maka perusahaan cenderung memilih mendanai kegiatan operasionalnya dengan dana internal terlebih dahulu. Tingkat profitabilitas yang tinggi mengindikasi bahwa perusahaan optimal dalam pengelolaan aset, jadi laba bersih yang diperoleh dari kegiatan operasional dapat digunakan untuk memenuhi kebutuhan pendanaan tanpa menggunakan hutang.

Namun hasil penelitian ini berbeda dengan penelitian Setyawan \& Nuzula(20161. Teori trade off, sejalan dengan penelitian ini yaitu perusahaan yang profitabilitasnya tinggi, tingkat pajak yang dibayarkan juga tinggi sehingga untuk mengurangi pembayaran pajak maka digunakanlah hutang. Biaya bunga dari penggunaan hutang dapat digunakan untuk mengurangi pembayaran pajak. Jadi, penggunaan hutang ini dimanfaatkan oleh perusahaan untuk mengurangi pembayaran pajak.

4. Hipotesis keempat dalam penelitian ini, yaitu variabel Tangibility memiliki pengaruh positif dan nyata terhadap struktur modal. Sesuai hasil tes bisa dilihat bahwa nilai probabilitas dari variabel Tangibility sebesar $0,042<0,05$ dengan nilai t-Statistik sebesar $-2,113$. Hal ini berarti bahwa H4 ditolak, dimana terdapat pengaruh negatif signifikan Tangibility terhadap Struktur Modal.

Penelitian dari Setyawan \& Nuzula (2016) dan dari Wijaya \& Jessica, (2018) mendukung hasil penelitian ini sehingga dapat diinterpretasikan bahwa apabila tingkat tangibility pada suatu perusahaan meningkat maka struktur modalnya menurun dan sebaliknya. Semakin tinggi tingkat tangibility maka untuk memenuhi kebutuhan pendanaannya perusahaan tidak akan kekurangan, 
karena perusahaan menghasilkan laba yang stabil karena memiliki tangibility yang besar (Setyawan \& Nuzula, 2016).

Akan tetapi penelitian yang dilakukan oleh Corina, Murhadi, \& Wijaya (2017) berlawanan dengan penelitian ini. Hasil penelitian tersebut menjelaskan bahwa semakin tinggi tingkat tangibility maka tingkat hutangnya juga meningkat. Perusahaan yang mempunyai nilai tangible aset yang besar maka perusahaan tersebut berada pada posisi yang memungkinkan untuk melakukan pinjaman, karena dengan aset tersebut dapat digunakan sebagai jaminan pinjaman. Perbedaan hasil dari beberapa penelitian diatas disebabkan oleh perbedaan objek dan periode yang digunakan.

5. Hipotesis kelima, yaitu Growth Opportunity memberikan pengaruh negatif signifikan terhadap Struktur Modal . Berdasarkan hasil pengujian didapatkan nilai probabilitas variabel Growth Opportunity sebesar 0,009<0,05 dengan nilai t-Statistik sebesar -2,791. Hal ini berarti H5 diterima, variabel struktur modal diberikan pengaruh negatif signifikan oleh Growth Opportunity.

Hasil dari penelitian ini sesuai dengan penelitian dari Setyawan \& Nuzula(2016). Hasil penelitian ini menegaskan bahwa tingkat hutangnya akan menurun jika growth opportunity mengalami kenaikan dan sebaliknya. Hal ini disebabkan oleh tingkat peluang pertumbuhan perusahaan yang tinggi cenderung untuk menahan keuntungan yang diperoleh guna membiayai pertumbuhan. Potensi pertumbuhan perusahaan yang tinggi memberikan kemungkinan perusahaan mempunyai biaya pendanaan ekuitas rendah karena perusahaan lebih memilih melakukan pendanaan dengan dana internalnya [20].

Penelitian yang dilakukan oleh Wijaya \& Jessica(2018) tidak sejalan dengan hasil penelitian ini.Hasil penelitian tersebut menjelaskan bahwa growth opportunity yang dimiliki suatu perusahaan tinggi memiliki kemungkinan untuk menggunakan utang yang tinggi pula dalam pembiayaan operasionalnya disebabkan oleh tidak mencukupinya dana internal untuk membiayai operasional perusahaan, sehingga untuk menutupi kekurangannya maka perlu menggunakan hutang. Perbedaan hasil penelitian dapat disebabkan oleh objek dan periode yang digunakan memiliki perbedaan.

Berdasarkan hasil pengujian sebelumnya, dapat dilihat bahwa besarnya probabilitas (FStatistik) sebesar $0,000<0,05$, yang artinya bahwa seluruh variabel bebas, yaitu Size, Likuiditas, Profitabilitas, Tangibility, danGrowth Opportunitysecara simultan memberikan pengaruh signifikan terhadap struktur modal.

Berdasarkan uji $\mathrm{R}^{2}$ terlihat bahwa nilai Adjusted R2, yaitu sebesar 0,455. Hal ini menunjukkan bahwa variasi variabel Struktur Modal diinterpretasikan oleh variable Size, Likuiditas, Profitabilitas, Tangibility, dan Growth Opportunity sebesar 45,5\% sedangkan 54,5\% dijelaskan oleh faktor-faktor selain model regresi yang dibentuk.

\section{Kesimpulan}

Berdasarkan penelitian yang dilakukan mengenai pengaruh firms size, liquidity, profitability, tangibility, dan growth opportunity terhadap struktur modal dapat diambil kesimpulan bahwa Firm Size (Ukuran Perusahaan) dan profitabilitas terhadap Struktur Modal pada perusahaan yang terdaftar di Jakarta Islamix Index periode 2008-2017 tidak memiliki 
pengaruh yang signifikan.Kemudian ada pengaruh negatif dan signifikan dari Likuiditas, Tangibality, dan variabel Growth Opportunity terhadap variabel Struktur Modal pada perusahaan yang terdaftar di Jakarta Islamix Index periode 2008-2017.

Kedepan penelitian diharapkan diperpanjang masa pengamatannya dan ditambahkan variabel yang mempengaruhi lainnya berdasarkan teori yang ada,sehingga hasilnya dapat lebih kuat dan komprehensif daripada penelitian sebelumnya.

\section{References}

[1] Yudhiarti, R., \& Mahfud, M. K.: Analisis Faktor-Faktor Yang Mempengaruhi Struktur Modal (Pada Perusahaan Manufaktur Yang Terdaftar Di Bursa Efek Indonesia Periode Tahun 2010-2014). Diponegoro Journal Of Management, 5(3), 462-474 (2016)

[2] Margaretha, F., \& Ginting, K. R.: Faktor-Faktor Yang Mempengaruhi Struktur Modal Pada Perusahaan Bumn Di Indonesia. Jurnal Ekonomi Universitas Esa Unggul, 7(01) (2016)

[3] Sheikh, N. A., \& Qureshi, M. A.: Determinants Of Capital Structure Of Islamic And Conventional Commercial Banks: Evidence From Pakistan. International Journal Of Islamic And Middle Eastern Finance And Management, 10(1), 24-41. Https://Doi.Org/10.1108/Imefm-10-2015-0119 (2017)

[4] Kanita, G. G.: Pengaruh Struktur Aktiva Dan Profitabilitas Terhadap Struktur Modal Perusahaan Makanan Dan Minuman. Trikonomika, 13(2), 127-135 (2017)

[5] Ayunda, P. P., \& Prasetiono, P.: Analisis Faktor-Faktor Yang Mempengaruhi Struktur Modal Pada Perusahaan Manufaktur Yang Terdaftar Di Bursa Efek Indonesia (Bei) Pada Tahun 2007-2011 (Phd Thesis). Fakultas Ekonomika Dan Bisnis (2013)

[6] Lestari, H., \& Yarni, N.: Analisis Faktor-Faktor Yang Mempengaruhi Struktur Modal Pada Perusahaan Manufaktur Yang Terdaftar Di Bei (Phd Thesis) (2017)

[7] Lestari, H., \& Yarni, N.: Analisis Faktor-Faktor Yang Mempengaruhi Struktur Modal Pada Perusahaan Manufaktur Yang Terdaftar Di Bei (Phd Thesis) (2017)

[8] Toni, A. A.: Faktor-Faktor Yang Mempengaruhi Struktur Modal Perusahaan Manufaktur Di Bursa Efek Indonesia. Jurnal Benefita : Ekonomi Pembangunan, Manajemen Bisnis Dan Akuntansi, 1(2), 78-94. Https://Doi.Org/10.22216/Benefita.V1i2.1429 (2016)

[9] Lestari, H., \& Yarni, N.: Analisis Faktor-Faktor Yang Mempengaruhi Struktur Modal Pada Perusahaan Manufaktur Yang Terdaftar Di Bei (Phd Thesis) (2017)

[10] Sheikh, N. A., \& Qureshi, M. A.: Determinants Of Capital Structure Of Islamic And Conventional Commercial Banks: Evidence From Pakistan. International Journal Of Islamic And Middle Eastern Finance And Management, 10(1), 24-41. Https://Doi.Org/10.1108/Imefm-10-2015-0119 (2017)

[11] Wangsawinangun, R. Z.: Penetapan Struktur Modal Yang Optimal Dalam Upaya Meningkatkan Nilai Perusahaan (Studi Pada Pt. Astra International, Tbk Dan Anak Perusahaan Tahun 2008-2012). Jurnal Administrasi Bisnis, 9(2) (2014)

[12] Murti, A. A.: Analisis Faktor-Faktor Yang Mempengaruhi Struktur Modal Pada Perusahaan Real Estate Dan Properti. Jurnal Ilmu Manajemen (Jim), 2(2) (2014)

[13] Sholahuddin, M., \& Purwaningtyas, Y.: Analisis Data Panel Terhadap Profitabilitas Bank Syariah Di Indonesia. Proceeding Of The Urecol, 233-242 (2018)

[14] Chandra, T.: Faktor-Faktor Yang Memengaruhi Struktur Modal Pada Perusahaan Properti Dan Real Estate Di Indonesia. Ekuitas: Jurnal Ekonomi Dan Keuangan, 18(4), 507-523 (2018) 
[15] Ferdiansya, M. S.: Faktor-Faktor Yang Mempengaruhi Struktur Modal Pada Perusahaan Pertambangan Yang Terdaftar Di Bursa Efek Indonesia. Jurnal Manajemen Dan Bisnis Sriwijaya, 11(2), 133-148 (2013)

[16] Wijaya, E., \& Jessica, J.: Analisa Pengaruh Struktur Aktiva, Ukuran Perusahaan, Profitabilitas, Growth Opportunity, Tangibility, Bussiness Risk Dan Likuiditas Terhadap Struktur Modal Perusahaan Pada Sektor Property \& Real Estate Yang Terdaftar Di Bursa Efek Indonesia Pada Tahun 2011-2015. Procuratio (Jurnal Ilmiah Manajemen), 5(4), 440451 (2018)

[17] Wijaya, E., \& Jessica, J.: Analisa Pengaruh Struktur Aktiva, Ukuran Perusahaan, Profitabilitas, Growth Opportunity, Tangibility, Bussiness Risk Dan Likuiditas Terhadap Struktur Modal Perusahaan Pada Sektor Property \& Real Estate Yang Terdaftar Di Bursa Efek Indonesia Pada Tahun 2011-2015. Procuratio (Jurnal Ilmiah Manajemen), 5(4), 440451 (2018)

[18] Hudan, Y., Isynuwardhana, D., \& Triyanto, D. N.: Pengaruh Profitabilitas, Likuiditas, Dan Ukuran Perusahaan Terhadap Struktur Modal Perusahaan (Pada Perusahaan Pertambangan Subsektor Batubara Yang Terdaftar Di Bursa Efek Indonesia Tahun 2011-2015). Eproceedings Of Management, 3(2) (2016)

[19] Liem, J. H., Murhadi, W. R., \& Sutejo, B. S.: Faktor-Faktor Yang Mempengaruhi Struktur Modal Pada Industri Consumer Goods Yang Terdaftar Di Bei Periode 2007-2011. Calyptra, 2(1), 1-11 (2013)

[20] Setyawan, A. I. W., \& Nuzula, N. F.: Pengaruh Firm Size, Growth Opportunity, Profitability, Business Risk, Effective Tax Rate, Asset Tangibility, Firm Age Dan Liquidity Terhadap Struktur Modal Perusahaan (Studi Pada Perusahaan Sektor Property Dan Real Estate Yang Terdaftar Di Bei Tahun 200. Jurnal Administrasi Bisnis, 31(1), 108-117 (2016) 